\title{
Description of a new species of Marionia (Gastropoda: Heterobranchia: Tritoniidae) from the Gulf of Guinea (eastern Atlantic Ocean)
}

\author{
' Departamento de Biología, \\ Facultad de Ciencias del Mar \\ y Ambientales; Campus de \\ Excelencia Internacional del \\ Mar (CEI·MAR), Av. República \\ Saharaui, s/n, Ap. 40, 11510 \\ Puerto Real (Cádiz), Spain.
}

${ }^{2}$ BIOCON Research Group, IUECOAQUA, Universidad de Las Palmas de Gran Canaria; Islas Canarias, Spain.

${ }^{3}$ Departamento de Biología, Facultad de Ciencias, Universidad Autónoma de Madrid; Campus de Excelencia Internacional UAM + CSIC, Cl Darwin, 2, 28049 Madrid, Spain.

${ }^{4}$ Centro de Investigación en Biodiversidad y Cambio Global (CIBC-UAM); Campus de Excelencia Internacional UAM + CSIC C/Darwin 2, 28049 Madrid, Spain.

${ }^{5}$ Instituto Universitario de Investigación Marina (INMAR), Campus de Excelencia Internacional del Mar (CEI·MAR), Universidad de Cádiz, Av.

República Saharaui, s/n, Ap. 40 11510 Puerto Real (Cádiz), Spain.

* Corresponding author email: <felipe.devasconcelos@uca.es>.

Date Submitted: 28 December, 2018. Date Accepted: 16 April, 2019. Available Online: 17 April, 2019.

\author{
Felipe De Vasconcelos Silva ${ }^{*}$ \\ Aketza Herrero-Barrencua ${ }^{2}$ \\ Marta Pola ${ }^{3,4}$ \\ Juan Lucas Cervera ${ }^{1,5}$
}

\begin{abstract}
A new species of dendronotid nudibranch, Marionia abrahamorum sp. nov., is described here. This species was found on Príncipe Island (Gulf of Guinea, eastern Atlantic Ocean), and its description is based on its morphological characteristics as well as molecular data from two mitochondrial (cytochrome c oxidase subunit I and 16S rRNA) markers and one nuclear (histone-3) marker. This species differs from all known Tritoniidae in terms of its size, color pattern, notum pattern, number of velar processes, number of gills, presence of stomach plates, and radular formula. The phylogenetic results support the results of the morphological analysis, confirming its placement within the genus Marionia.
\end{abstract}

Sea slugs from the family Tritoniidae (Nudibranchia, Cladobranchia, Dendronotidae) span a variety of sizes and colors, but they feed exclusively on octocorals (McDonald and Nybakken 1999). The eight currently valid genera are Tritonia, Tritoniopsis, Tritoniella, Marionia, Marioniopsis, Marianina, Paratritonia, and Tochuina (Pola and Gosliner 2010, Bertsch 2014, Hulett et al. 2015), with a recent inclusion (Bertsch et al. 2009) and subsequent exclusion (Bertsch 2014) of the genus Trivettea. Among the accepted genera, Marionia is the second-most speciose, with 28 accepted species, including most of the largest species in the family. On his 
last revision of this family, Odhner (1963) rediagnosed Marionia as having stomach plates, a digestive gland divided into two masses, jaws with three to six rows of fine denticles, a radula possessing tricuspid central teeth with differentiated first lateral teeth, gills branched and of uniform size, and compound velar papillae. Since most of these characters require a thorough internal morphological study, identifications performed in situ or based only on external characters can easily misdirect researchers to other genera in Tritoniidae. Furthermore, the differences among the genera included in the family have become blurred since Odhner (1963), with descriptions ranging from those lacking information on important details of the internal anatomy, i.e., Tritonia taliartensis Ortea and Moro, 2009 and Marionia ghanensis Edmunds and Carmona, 2017, to those in which characters create doubt about which genus the species should be assigned to, such as the unique presence of stomach plates in Tritonia odhneri Er. Marcus, 1959, among the Tritonia, or the unicuspid rachidian in Tritonia khaleesi Silva, Azevedo and Matthews-Cascon, 2014.

Most species of Marionia have been recorded in the Indo-Pacific region (Smith and Gosliner 2007, Gosliner et al. 2008, García and Bertsch 2009), with only nine found in the Atlantic Ocean as follows: Marionia blainvillea Risso, 1818, Marionia cucullata (Couthouy, 1852), Marionia cabindae White, 1955, Marionia vanira Ev. Marcus and Er. Marcus, 1966, Marionia pusa Ev. Marcus and Er. Marcus, 1968, Marionia tedi Ev. Marcus, 1983, Marionia limceana Silva, Meirelles and MatthewsCascon, 2013, Marionia ghanensis Edmunds and Carmona, 2017, and Marionia gemmi Almón, Pérez and Caballer, 2018 (see MolluscaBase 2018).

From October to November of 2016, field sampling was performed along the coasts of Príncipe Island (declared by UNESCO as Reserve of Biosphere in 2012) to create a map of the marine habitats, as well as to examine the poorly known marine flora and fauna of Príncipe Island in detail. The resulting collection included specimens of an unknown reddish tritoniid whose internal anatomy revealed that they belong to the genus Marionia. To confirm the taxonomic status of these specimens, we performed molecular phylogenetic and species delimitation analyses based on two mitochondrial [cytochrome c oxidase subunit (COI) and 16S rRNA (16S)] markers and one nuclear [histone-3 (H3)] marker, as well as a complete and detailed anatomical study. The new species is compared with other congeneric Atlantic species and with one reddish species from the Indian-Pacific region.

\section{Material AND Methods}

Samples for Morphological Studies.-Four specimens of an undescribed species of Marionia were collected by scuba diving on the shallow called Pedra Mitade $\left(01^{\circ} 32^{\prime} \mathrm{N}\right.$, $\left.7^{\circ} 25^{\prime} \mathrm{E}\right)$ off Príncipe Island, São Tomé and Príncipe. These specimens were observed and photographed under an optical microscope, and the results were compared with data from the literature on other species in this genus. Three specimens were dissected for the study of the internal organs. Their internal features were examined and drawn using a dissecting microscope and camera lucida. Special attention was paid to the morphology of the digestive and reproductive systems. The buccal mass was removed and dissolved in $10 \%$ sodium hydroxide until the radula and the jaws were isolated from the surrounding tissue. The radula and jaws were then rinsed in water, dried, and mounted for examination with a LEO 1430VP scanning electron microscopy. The specimens are deposited at the Museu Nacional de História e da Ciência de 
Lisboa (MB) under voucher numbers MB28-005053, MB28-005054, MB28-005055, and MB28-005056.

Samples for Molecular Studies.-The specimens MB28-005053, MB28-005054, and MB28-005055 were used for the molecular analyses. We also included one specimen of an unidentified Marionia sp., which is henceforth known as "Marionia sp. 1," which was collected from the Gulf of Cadiz, southwest Iberian Peninsula $\left(06^{\circ} 28.7^{\prime} \mathrm{W}\right.$, $36^{\circ} 16.3^{\prime} \mathrm{N}$ ), to provide better taxon sampling. This specimen was deposited at the Museu Nacional de História e da Ciência de Lisboa (MB) under voucher number MB28-005057.

DNA Extraction, Amplification, and Sequencing.-DNA extractions were performed using a Qiagen DNeasy Blood and Tissue Kit according to the manufacturer's instructions, with some minor changes (a 100- $\mu \mathrm{L}$ final elution instead of $200 \mu \mathrm{L}$ ). Partial sequences of COI, 16S, and $\mathrm{H} 3$ were amplified by polymerase chain reaction (PCR) using the universal primers LCO1490 and HCO2198 for COI (Folmer et al. 1994), 16S ar-L and 16S br-H for 16S (Palumbi et al. 1991), and H3AD5'3' and H3BD5'3' for H3 (Colgan et al. 1998). The master mix for the PCR was based on 25$\mu \mathrm{l}$ volume reactions. Each PCR contained $2.5 \mu \mathrm{l}$ of Qiagen buffer, $3 \mu \mathrm{l}$ of DNA, $2.5 \mu \mathrm{l}$ of dNTP ( $2 \mathrm{mM}$ ), $5 \mu \mathrm{l}$ of Q-solution (Qiagen), 1.5-3.5 $\mu \mathrm{M}$ magnesium chloride, $1.5 \mu \mathrm{l}$ of each forward and reverse primer $(10 \mu \mathrm{M}), 0.25 \mu \mathrm{l}$ of DNA polymerase (250 units $\mu^{-1}$ ), and nuclease-free water. Successful PCR products were purified and sequenced by Macrogen, Inc. (Netherlands). All the resulting new sequences were deposited in GenBank. COI amplification was performed with an initial denaturation for $3 \mathrm{~min}$ at $94-95^{\circ} \mathrm{C}$, followed by $39-40$ cycles of $30-45 \mathrm{~s}$ at $94{ }^{\circ} \mathrm{C}$ (denaturation), 30-45 s at 42 ${ }^{\circ} \mathrm{C}$ (annealing temperature), and $1-2 \mathrm{~min}$ at $72{ }^{\circ} \mathrm{C}$ (extension) with a final extension of 5 min at $72{ }^{\circ} \mathrm{C}$. A $16 \mathrm{~S}$ amplification was performed with an initial denaturation for 3 min at $94-95^{\circ} \mathrm{C}$, followed by 39 cycles of $39-45 \mathrm{~s}$ at $94{ }^{\circ} \mathrm{C}, 30-50 \mathrm{~s}$ at $45^{\circ} \mathrm{C}$ (annealing temperature), and $2 \mathrm{~min}$ at $72{ }^{\circ} \mathrm{C}$, with a final extension of $5-10 \mathrm{~min}$ at $72{ }^{\circ} \mathrm{C}$. $\mathrm{H} 3$ amplification was performed with an initial denaturation for $3 \mathrm{~min}$ at $95^{\circ} \mathrm{C}$, followed by 40 cycles of $45-60 \mathrm{~s}$ at $94-95^{\circ} \mathrm{C}, 45 \mathrm{~s}$ at $50^{\circ} \mathrm{C}$ (annealing temperature), and $2 \mathrm{~min}$ at $72{ }^{\circ} \mathrm{C}$, with a final extension of $10 \mathrm{~min}$ at $72^{\circ} \mathrm{C}$.

Phylogenetic Analyses. - We successfully obtained seven new sequences from our undescribed Marionia on Príncipe Island; the sequences of COI, 16S, and H3 were obtained from MB28-005053, but COI amplifications for MB28-005054 and MB28005055 were not successful, resulting in a total of one sequence of COI, three of 16S, and three of H3. Additionally, we obtained COI, 16S, and H3 sequences for Marionia sp. 1 (MB28-005057). In addition to the 10 new sequences obtained in this study, 99 additional sequences from different Tritoniidae species were retrieved from GenBank, along with nine sequences from three species in the families Arminidae, Hancockiidae, and Pleurobranchidae as follows: Armina semperi (Bergh, 1866), Hancockia californica MacFarland, 1923, and Pleurobranchus areolatus Mörch, 1863, respectively, which were included as outgroups following recent molecular studies of the family (Pola and Gosliner 2010, Hulett et al. 2015, Goodheart 2017). All the species and sequences used in this study, including the sequences retrieved from GenBank, are listed in Table 1. 
Table 1. Specimens used for molecular analyses, vouchers, and GenBank accession numbers. New sequences obtained in this study are in bold.

\begin{tabular}{|c|c|c|c|c|}
\hline Species & Voucher & $16 \mathrm{~S}$ & $\mathrm{COI}$ & H3 \\
\hline Pleurobranchus areolatus & CPIC00829 & KM521755 & KM521756 & KM521617 \\
\hline Armina semperi & CASIZ177534 & HM162606 & HM162696 & HM162512 \\
\hline Hancockia californica & CASIZ175722 & HM162621 & HM162702 & HM162527 \\
\hline Marianina rosea & CASIZ175746 & HM162656 & HM162733 & HM162565 \\
\hline Marionia abrahamorum sp. nov. & MB28005053 & МН892386 & МH892390 & MH892392 \\
\hline Marionia abrahamorum sp. nov. & MB28005054 & МH892387 & - & MH892393 \\
\hline Marionia abrahamorum sp. nov. & MB28005055 & МH892388 & - & MH892394 \\
\hline Marionia arborescens & CASIZ177735 & KP226859 & KP226855 & KP226857 \\
\hline Marionia blainvillea & CASIZ176812 & HM162645 & HM162721 & HM162553 \\
\hline Marionia blainvillea & - & KY629594 & KY629603 & KY629612 \\
\hline Marionia blainvillea & - & KY629593 & KY629604 & KY629613 \\
\hline Marionia distincta & CASIZ110364 & KP226860 & KP226856 & KP226858 \\
\hline Marionia distincta & CASIZ173317 & HM162648 & HM162725 & HM162557 \\
\hline Marionia sp. 1 & MB28005057 & МH892389 & МH892391 & MH892395 \\
\hline Marionia levis & CASIZ173454 & HM162654 & HM162731 & HM162563 \\
\hline Marionia levis & CASIZ192357A & HM162655 & HM162732 & HM162564 \\
\hline Marionia levis & CASIZ192357B & KP153268 & KP153301 & KP153334 \\
\hline Marionia sp. 2 & CASIZ166891 & KP153267 & KP153300 & KP153333 \\
\hline Tritonia antarctica & CASIZ171177 & KP153269 & KP153302 & KP153335 \\
\hline Tritonia festiva & CASIZ186478 & HM162653 & HM162730 & HM162562 \\
\hline Tritonia hamnenorum & CASIZ181095 & KP153259 & KP153292 & KP153325 \\
\hline Tritonia hamnenorum & CASIZ181090 & KP153260 & KP153293 & KP153326 \\
\hline Tritonia manicata & KY629602 & KP153276 & KP153309 & KP153342 \\
\hline Tritonia nilsodhneri & CASIZ176218A & KP153272 & KP153305 & KP153338 \\
\hline Tritonia nilsodhneri & CASIZ176218B & KP153275 & KP153308 & KP153341 \\
\hline Tritonia nilsodhneri & CASIZ176218C & KP153263 & KР153296 & KP153329 \\
\hline Tritonia nilsodhneri & CASIZ176219 & HM162641 & HM162716 & HM162548 \\
\hline Tritonia nilsodhneri & CASIZ176222 & KP871702 & KP871653 & KP871677 \\
\hline Tritonia pickensi & CASIZ175718 & HM162642 & HM162717 & HM162549 \\
\hline Tritonia striata & BAU2695 & LT596542 & LT596540 & LT615407 \\
\hline Tritonia striata & BAU2696 & LT596543 & LT596541 & LT615408 \\
\hline Tritoniidae sp. 1 & CASIZ 189262A & KP153276 & KP153309 & KP153342 \\
\hline Tritoniidae sp. 2 & CASIZ 189311A & KP153272 & KP153305 & KP153338 \\
\hline Tritoniidae sp. 3 & CASIZ189311B & KP153273 & KP153306 & KP153339 \\
\hline Tritoniidae sp. 4 & CASIZ189311C & KP153274 & KP153307 & KP153340 \\
\hline Tritoniidae sp. 5 & CASIZ189419 & KP153277 & KP153310 & KP153343 \\
\hline Tritoniidae sp. 6 & CAS189459 & KP153275 & KP153308 & KP153341 \\
\hline Tritoniopsis alba & CASIZ69928 & KP153281 & KP153314 & KP153347 \\
\hline Tritoniopsis alba & CASIZ69980 & KP153282 & KP153315 & KP153348 \\
\hline Tritoniopsis frydis & CASIZ181156 & KP153278 & KP153311 & KP153344 \\
\hline
\end{tabular}

The DNA sequences were assembled, edited, and aligned using Geneious 10.2.2 (Kearse et al. 2012). All the sequences were checked for contamination with BLAST (Altschul et al. 1990) as implemented in the GenBank database. The protein-coding sequences were translated into amino acids to confirm the alignments. Pairwise uncorrected $p$-distances were calculated in MEGA 7.0 (Tamura et al. 2011). The 
levels of substitution saturation in the individual gene sequence alignments were investigated using the test developed by Xia et al. (2003) and Xia and Lemey (2009) in DAMBE (Xia and Xie 2001). The convergence of phylogenetic trees generated in MrBayes was confirmed by eye using the Trace function in Tracer 1.5 (Rambaut et al. 2014). The most variable regions from the $16 \mathrm{~S}$ rRNA alignment were removed in the first analyses, using both the default settings and the standard options for stringent and less stringent selections in Gblocks based on studies in which the elimination of ambiguous data in the non-protein-coding gene leads to significantly better phylogenetic trees depending on the size of the alignment (Jeffroy et al. 2006, Talavera and Castresana 2007). However, when these regions were excluded from the analyses, the combined phylogenetic tree showed low node support. Therefore, final analyses were performed by including all the bases.

We conducted phylogenetic analyses for each data set of COI (658 bp), H3 (328 bp), and $16 \mathrm{~S}$ (462 bp) separately, in addition to two concatenated combinations (COI+16S and $\mathrm{COI}+\mathrm{H} 3+16 \mathrm{~S})$. All the taxa were included for the concatenated analysis of the three markers (total of 118 sequences). The COI+16S data set included four partitions (COI- $1^{\text {st }}, \mathrm{COI}-2^{\text {nd }}, \mathrm{COI}-3^{\text {rd }}$, and $\left.16 \mathrm{~S}\right)$. The $\mathrm{COI}+\mathrm{H} 3+16 \mathrm{~S}$ data set included seven partitions $\left(\mathrm{COI}-1^{\text {st }}, \mathrm{COI}-2^{\text {nd }}, \mathrm{COI}-3^{\text {rd }}, \mathrm{H} 3-1^{\text {st }}, \mathrm{H} 3-2^{\text {nd }}, \mathrm{H} 3-3^{\text {rd }}\right.$, and $\left.16 \mathrm{~S}\right)$. The best-fit evolution models for each data set were determined using the Akaike information criterion (Akaike 1974) as implemented in PartitionFinder 2 (Lanfear et al. 2016), resulting in TRN+G for COI- ${ }^{\text {st }}$, TRN $+\mathrm{I}$ for $\mathrm{COI}-2^{\text {nd }}$, TVM+I for COI-3 ${ }^{\text {rd }}, \mathrm{TIM}+\mathrm{I}$ for $\mathrm{H} 3-1^{\text {st }}, \mathrm{K} 81+\mathrm{I}$ for $\mathrm{H} 3-2^{\text {nd }}, \mathrm{HKY}+\mathrm{G}$ for $\mathrm{H} 3-3^{\text {rd }}$, and TVM+I+G for 16S. Maximum likelihood (ML) analyses were performed using RAxML software v8.2.4 (Stamatakis 2006), and the node support was assessed with a non-parametric bootstrap (BS) with 5000 replicates, random starting trees, and parameters estimated from each data set under the model selected for the original data set. Bayesian Inference (BI) analyses were conducted using MrBayes v3.1.2b (Ronquist and Huelsenbeck 2003) for five million generations with two independent runs and a sampling frequency of 1000 . The implemented models were the ones that were estimated with PartitionFinder 2. BI and ML phylogenetic analyses were performed on the 280-core "PhyloCluster" hosted at the Center for Comparative Genomics, California Academy of Sciences. Only the nodes supported by PP $\geq 0.95$ and BS $\geq 75$ were considered as resolved. The BI and ML trees were visualized, collapsed ( $\mathrm{PP} \geq 0.95, \mathrm{BS} \geq 75$ ), and edited in TreeGraph v2.7.1 (Stöver and Müller 2010). The final graphical editing of the trees was completed in Photoshop CS6.

An automatic barcode gap discovery (ABGD) (Puillandre et al. 2012) was performed twice, with the COI alignment (35 specimens, excluding the outgroup) and with the $16 \mathrm{~S}$ alignment (37 specimens, excluding the outgroup), using the online version of the software. ABGD was run using the following parameters: Jukes-Cantor and Kimura (80) Pmin $=0.001, \operatorname{Pmax}=0.1, \mathrm{NB}=20$, Steps $=10$, and relative gap width $=1$.

\section{Results}

The results of the substitution saturation test for each gene alignment showed significant $P$-values $(\leq 0.5)$ for all the gene alignments and index of substitution saturation (Iss) values that were less than the Iss.c (critical index of substitution saturation) in all cases, indicating little saturation (Table 2$)$. The combined data set $(\mathrm{COI}+\mathrm{H} 3+16 \mathrm{~S})$ 
Table 2. Results of substitution saturation tests for each gene alignment. Alignments with a significant $P$-value $(<0.05)$ and Iss (index of substitution saturation) < Iss.c (critical index of substitution saturation) show little saturation. Saturation tests were conducted for fully resolved sites only, in the program DAMBE. OTU= operational taxonomic units; $d f=$ degrees of freedom. Results were interpreted for symmetrical trees.

\begin{tabular}{lcccrrc}
\hline Data set & NumOTU & Iss & Iss.c & \multicolumn{1}{c}{ T } & \multicolumn{1}{c}{ df } & $P$ \\
\hline COI & 32 & 0.282 & 0.695 & 12.581 & 342 & $<0.0001$ \\
16S & 32 & 0.310 & 0.781 & 7.831 & 91 & $<0.0001$ \\
H3 & 32 & 0.122 & 0.702 & 17.286 & 126 & $<0.0001$ \\
\hline
\end{tabular}

yielded a sequence alignment of 1448 positions and provided better resolution than the COI, 16S, H3 (Online Figs. S1-S6) or COI+16S (1120 bp) separately (Online Figs. S7-S8). Figure 1 shows the phylogenetic hypothesis based on the combined data set $(\mathrm{COI}+\mathrm{H} 3+16 \mathrm{~S})$ constructed by BI. The topology of the ML tree (Online Fig. S9) was very similar to the one obtained by BI. The ML bootstrap values are shown in Figure 1 below their respective branches.

The monophyly of the Tritoniidae family was not recovered either by BI or ML due to the lack of resolution at the basal node (Fig. 1). The Tritoniidae species included in this analysis clustered in seven different clades without a relationship between them. Our new species from Príncipe Island appeared in a well-supported clade ( $\mathrm{PP}=1, \mathrm{BS}$ = 99) including Marionia sp. nov., M. blainvillea, Marionia arborescens Bergh, 1890, Marionia distincta Bergh, 1905, Marionia levis Eliot, 1904, Marionia sp. 1, Marionia

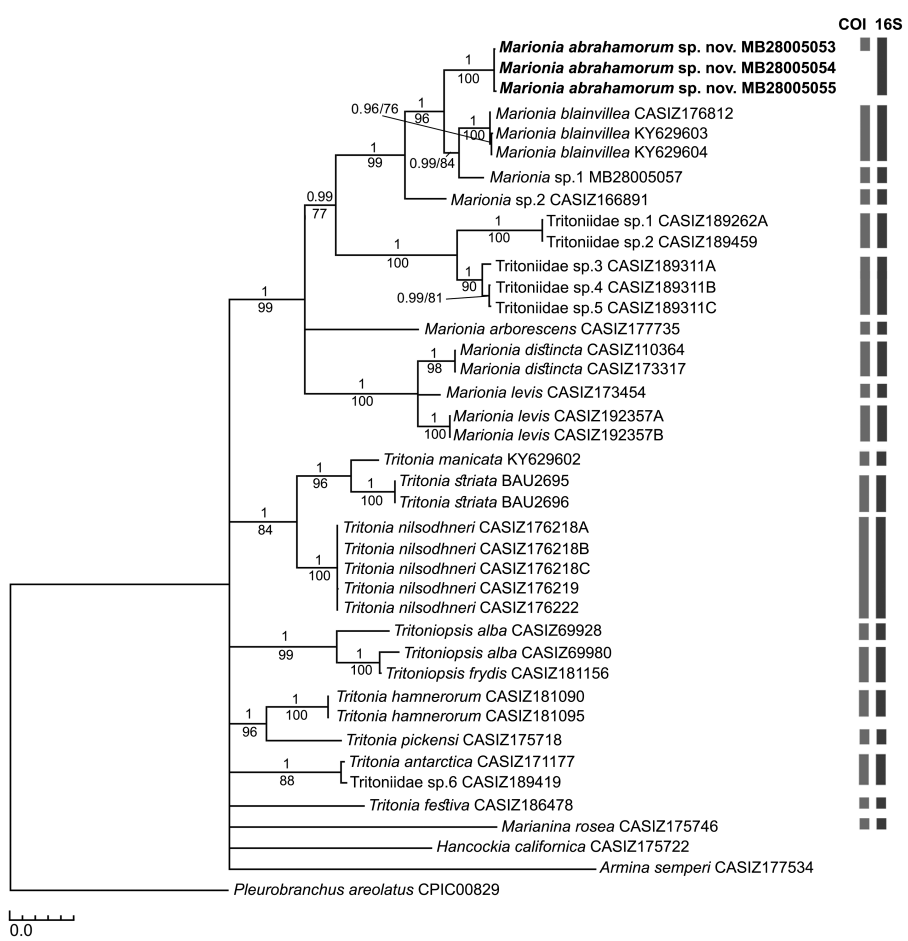

Figure 1. Bayesian phylogenetic tree based on the concatenated molecular data (COI+H3+16S). Bayesian posterior probabilities are shown above branches and maximum likelihood bootstrap values are shown below branches. Unsupported branches are not labelled. Rectangles are automatic barcode gap discovery groups (Jukes-Cantor and Kimura parameter) for the COI and 16S data set. 
Table 3. Maximum and minimum COI gene pairwise uncorrected $p$-distance between Marionia abrahamorum sp. nov. and other species of Tritoniidae.

\begin{tabular}{lc}
\hline Species & COI genetic distances (\%) \\
\hline Marionia blainvillea & 12 \\
Marionia sp. 1 & 13 \\
Marionia sp. 2 & 15 \\
Tritonia pickensi & 16 \\
Tritonia hamnerorum & 17 \\
Marionia distincta & 18 \\
Marionia levis & 18 \\
Tritonia antarctica & 18 \\
Tritonia festiva & 18 \\
Tritonia manicata & 18 \\
Tritoniidae sp. 3 & 18 \\
Tritoniidae sp. 5 & 18 \\
Marianina rosea & 19 \\
Tritonia nilsodhneri & 19 \\
Tritoniidae sp. 1 & 19 \\
Tritoniidae sp. 6 & 19 \\
Tritoniopsis alba & 19 \\
Marionia arborescens & 20 \\
Tritoniopsis frydis & 20 \\
Tritonia striata & 21 \\
\hline
\end{tabular}

sp. 2, and five undetermined species of Tritoniidae. In this clade, M. blainvillea was the sister taxon to Marionia sp. 1 ( $\mathrm{PP}=0.99, \mathrm{BS}=84$ ), and these two species clustered into a well-supported clade $(\mathrm{PP}=1, \mathrm{BS}=96)$ with $M$. sp. nov.

Within the clade that included $M$. sp. nov., the maximum interspecific pairwise uncorrected $p$-distance for COI was $20 \%$ between $M$. sp. nov. and $M$. arborescens, while the minimum was $12 \%$ between $M$. sp. nov. and $M$. blainvillea (Table 3 ). The maximum interspecific pairwise uncorrected $p$-distance for the COI found between $M$. sp. nov. and the remaining taxa was $21 \%$ with $T$. striata, while the minimum was 16\% with T. pickensi Ev. Marcus and Er. Marcus, 1967.

The ABGD species delimitation analysis recovered nine partitions with prior maximal distances from 0.001 to 0.059 using the COI alignment, and seven partitions with prior maximal distances from 0.001 to 0.021 using the $16 \mathrm{~S}$ alignment, with both the Jukes-Cantor (JC69) and Kimura (K80) parameters. All the partitions recovered with both data sets had 20 groups (Fig. 1), with the exception of Partition 1 (prior maximal distance, $P=0.001$ ) as recovered with the COI dataset, which had 21 groups. The phylogenetic analyses, the pairwise uncorrected $p$-distance and the species delimitation analyses all support the idea that our new specimens from Príncipe Island are in a distinct species belonging to the genus Marionia as described below. 


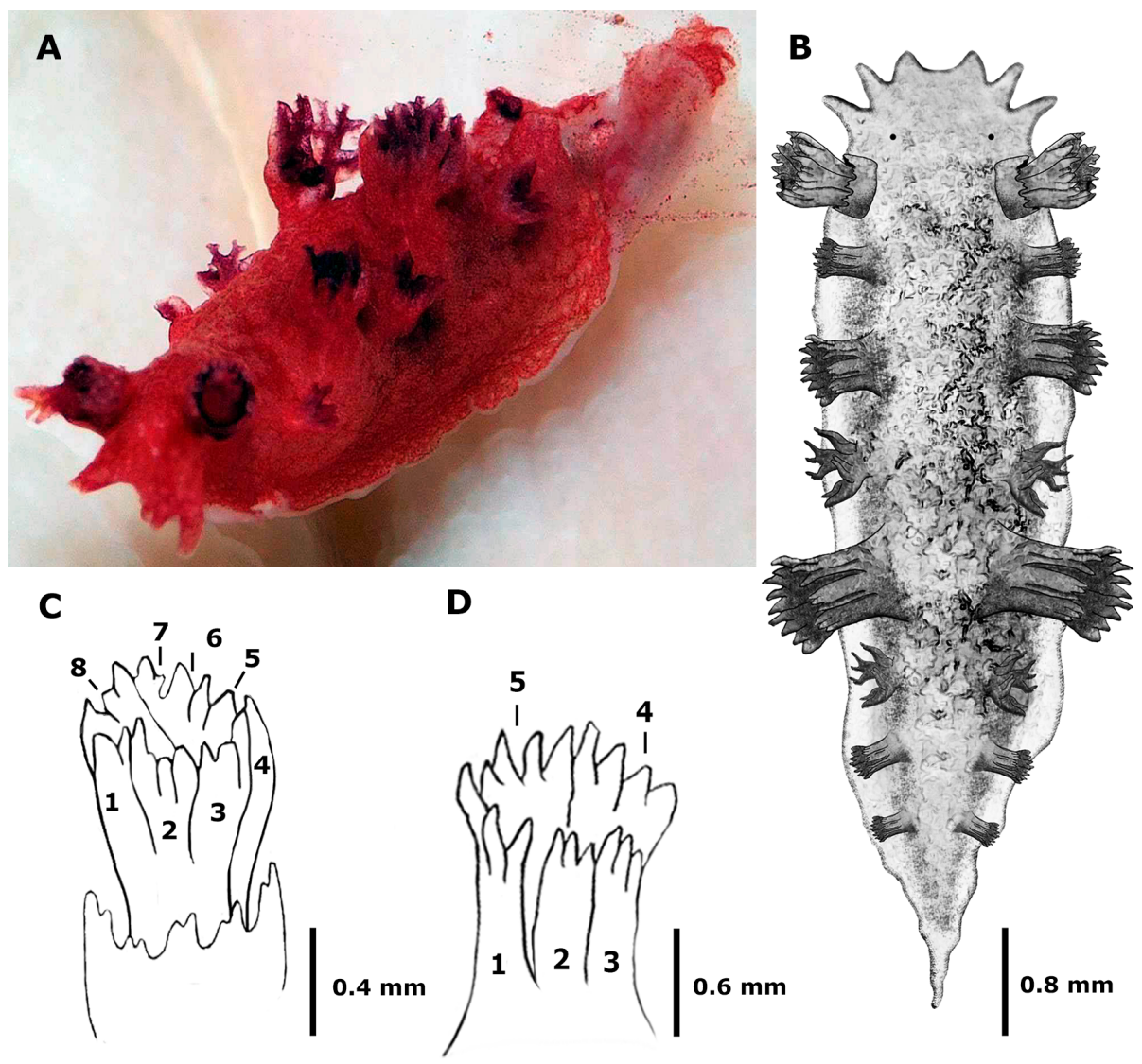

Figure 2. Marionia abrahamorum sp. nov. MB28-005053. (A) Digital photograph, mature adult, $12 \mathrm{~mm}$ in length; (B) line drawing of dorsal view; (C) line drawing, rhinophore with numbered plumes; (D) line drawing, gill with numbered plumes.

\section{SYSTEMATICS}

Family TRITONIIDAE Lamarck, 1809

Genus Marionia Vayssière, 1877

Marionia abrahamorum new species urn:lsid:zoobank.org:act:B5DAB4C8-6846-4DA1-A338-9E0A429781B0

(Figs. 2-6)

Material Examined.-MB28-005053, holotype, dissected and sequenced (COI, $16 \mathrm{~S}$ and H3), $12 \mathrm{~mm}$ in length preserved. Paratypes: MB28-005054, dissected and sequenced (16S and H3), $10 \mathrm{~mm}$ in length preserved; MB28-005055, dissected and sequenced (16S and H3), $7 \mathrm{~mm}$ in length preserved; MB28-005056, $6 \mathrm{~mm}$ in length preserved. All the specimens were collected at a depth of $16 \mathrm{~m}$ from Pedra Mitade, Príncipe Island, São Tomé and Príncipe, Gulf of Guinea $\left(01^{\circ} 32^{\prime} \mathrm{N}, 7^{\circ} 25^{\prime} \mathrm{E}\right)$, by A Herrero on November 27, 2016. 


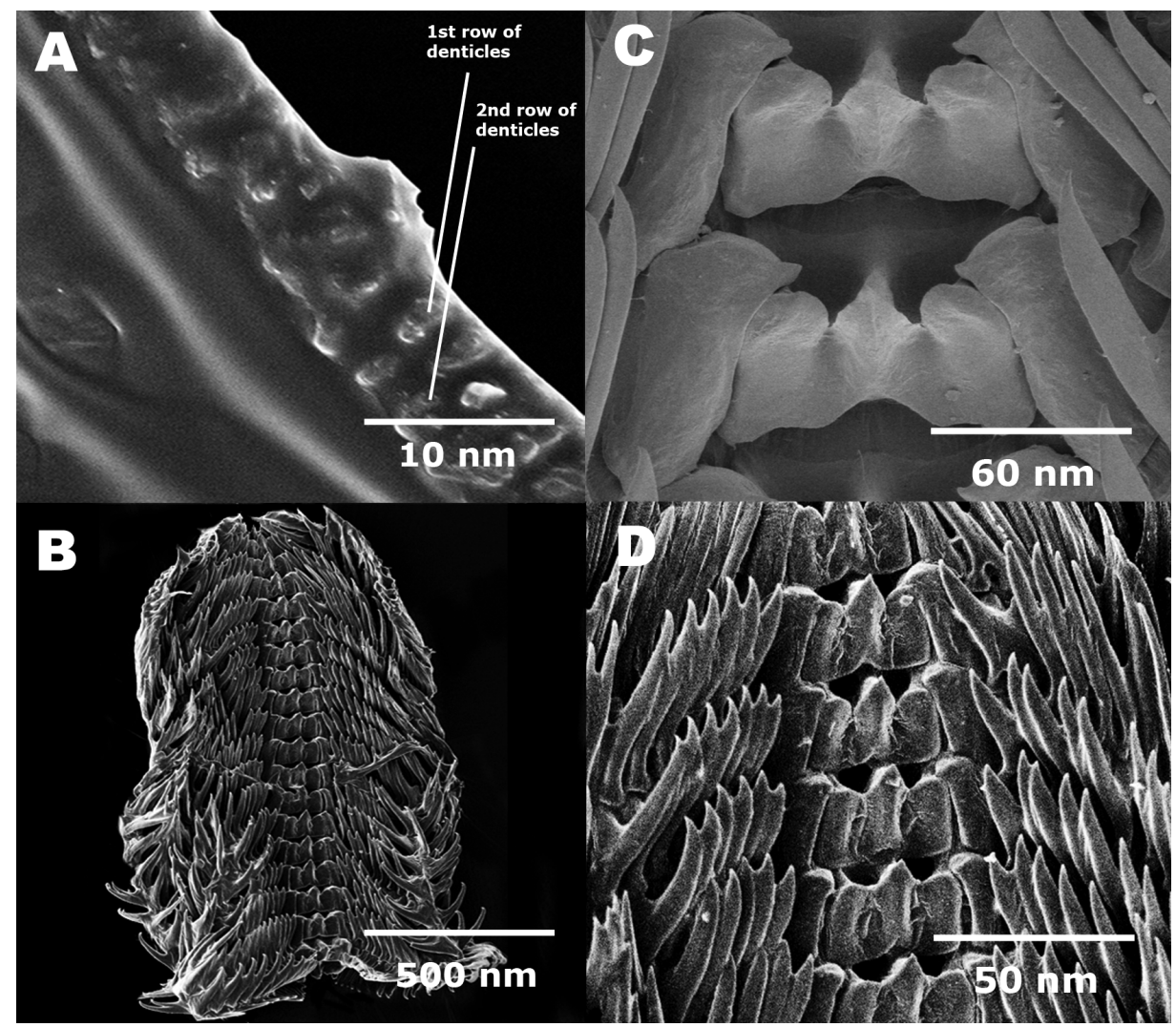

Figure 3. Marionia abrahamorum sp. nov. scanning electron micrographs. (A) Denticle rows from masticatory border of the jaws (MB28-005053); (B) overview of radula (MB28-005053); (C) rachidian tooth and first lateral tooth (MB28-005054); (D) central view of radula, with rachidian and lateral teeth (MB28-005053).

External Morphology (Fig. 2).--The body is slender, elongated, and red, with spots of lighter and darker shades along the notum, rhinophores, and gills (Fig. 2A). The notum is covered by small tubercles concentrated on the area anterior to the cardiac region. The mantle is wide, with an undulated margin. The foot is broad, rounded at the anterior region, and whitish along the margins. The mouth is located ventrally and anterior to the foot. The veil is slightly bilobed, containing six short digitiform appendages (Fig. 2B). The outermost anterior appendages are the largest, and they folded over themselves. The rhinophore sheaths have a crenulated margin divided into pairs of digital extensions. The retractable rhinophoral club has eight pinnate plumes, which are divided into three branches (Fig. 2C). All the specimens have seven gills on either side. The $1^{\text {st }}, 3^{\text {rd }}, 6^{\text {th }}$, and $7^{\text {th }}$ pairs of gills are small, while the $2^{\text {nd }}$ and $4^{\text {th }}$ are the largest. The gills have five pinnate branches, which are divided into one group of two and another of three (Fig. 2D), and they are usually organized in a cylindrical shape. The genital opening is large and located laterally between the $2^{\text {nd }}$ and $3^{\text {rd }}$ gills, while the anus is located laterally between the $3^{\text {rd }}$ and $4^{\text {th }}$ gills on the right side.

Anatomy (Figs. 3, 4, 5).-The jaws are broad, yellowish, with two rows of denticles on the inner edge (Fig. 3A), and they are easily recognizable in preserved animals in 


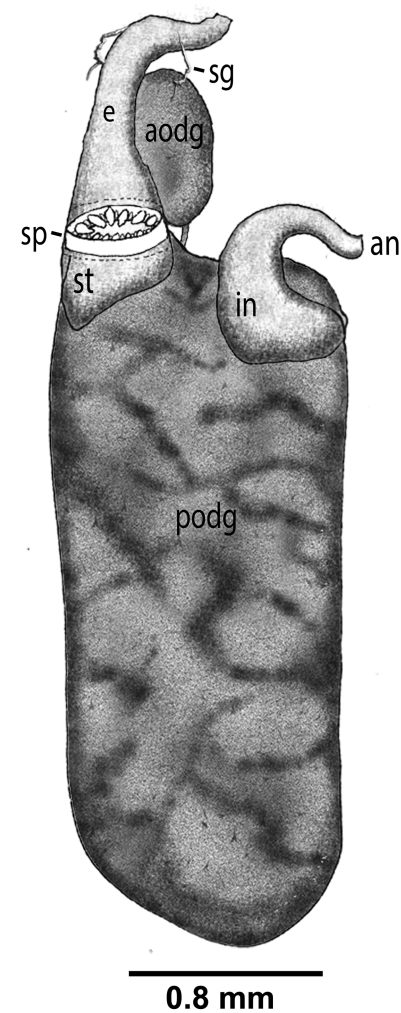

Figure 4. Marionia abrahamorum sp. nov. MB28-005053. Line drawing of the digestive system (dorsal view): an, anus; aodg, anterior part of the ovotestis-digestive gland complex; e, esophagus; in, intestine; podg, posterior part of the ovotestis-digestive gland complex; sg, salivary glands; sp, stomach plates; st, stomach.

external view. The radular formulae of two of the specimens are $20 \times 5-14.1 .1 .1 .5-14$ (MB28-005054) and $25 \times 10-16.1 .1 .1 .10-16$ (MB28-005053) (Fig. 3B). The rachidian tooth (Fig. 3C) is tricuspid with a long and sharp triangular central cusp, and blunt lateral cusps. The central cusp is worn in some cases. The first lateral teeth are short and broad, each with a pointed cusp curved towards the rachidian tooth. The remaining lateral teeth are long, slightly curved, and narrow (Fig. 3D). A pair of small and elongate salivary glands is visible on the outer wall of the proximal end of the esophagus and opens into the pharyngeal cavity (Fig. 4). The stomach is a large ovoid sac with a girdle of 36 triangular and yellowish stomach plates (MB28-005053 and MB28-005054); these detachable plates alternate in size, with a small one following a large one. Posterior to the girdle is an opening to the posterior ovotestis-digestive gland complex. The ovotestis-digestive gland complex is divided into two parts; the larger posterior part fills a large portion of the posterior region of the animal and is primarily formed by the ovotestis in mature specimens. The digestive gland lies at the core of both parts of the complex and is surrounded by the ovotestis. The anterior part of the complex is much smaller and is adjacent to the esophagus and the reproductive mass. A flat duct connects the two parts of the ovotestis-digestive gland complex (Fig. 4). 


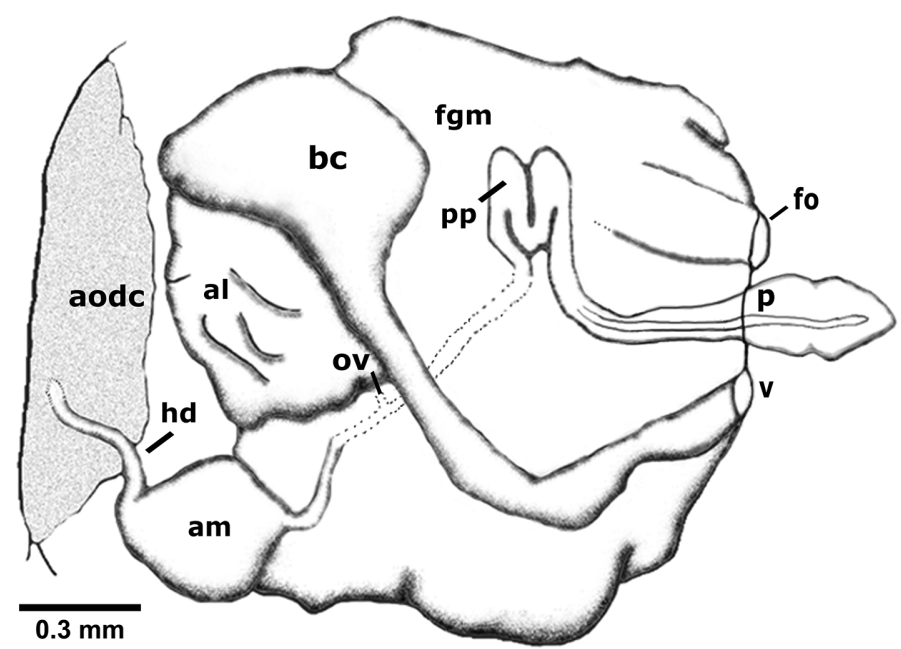

Figure 5. Marionia abrahamorum sp. nov. MB28-005053. Line drawing of the reproductive system, dorsal view: am, ampulla; al, albumen gland; aodc, anterior part of the ovotestis digestive gland complex; bc, bursa copulatrix; fgm, female gland mass; fo, female opening; hd, hermaphroditic duct; ov, oviduct; $p$, penis; pp, prostatic part of the deferent duct; v: vagina.

The reproductive system (Fig. 5) is androdiaulic. The whitish ovotestis is visible and covers the surface of the ovotestis-digestive gland complex. A narrow but long hermaphroditic duct arises from the anterior ovotestis-digestive gland complex and connects the ovotestis to the ampulla. The ampulla is small, slightly spherical, with no convolutions, and its connection to the vas deferens is concealed inside the female gland mass. The vas deferens emerges from this mass and becomes the flat and slender prostatic part that curves twice before turning into a bulbous and unarmed penis, which is extroverted in all the examined specimens. The bursa copulatrix is slightly elliptical and bulky, and is connected to the gonopore through a long vaginal duct. The albumen gland is discernible among the female gland mass. The female gland mass, together with the penis and the vagina, open to the exterior through a common atrium below the third gill.

Biology.-The specimens were found on an unidentified gorgonian, camouflaged with the same reddish color and with rhinophores and gills mimicking the gorgonian's polyps. Away from the gorgonian, the specimens changed their appearance: the rhinophores and gills were distinctly more extended and did not resemble a gorgonian's polyps as much (Fig. 2A).

Egg masses were found on the gorgonians, close to the specimens. They are narrow, slightly reddish, and transparent, with a characteristic constriction repeated almost regularly every few millimeters along the entire spawn. The eggs are small but distinguishable by the naked eye (Fig. 6B).

Type Locality and Habitat.-Pedra Mitade, Príncipe Island, São Tomé and Príncipe, Gulf of Guinea $\left(01^{\circ} 32^{\prime} \mathrm{N}, 7^{\circ} 25^{\prime} \mathrm{E}\right)$. All the Marionia abrahamorum sp. nov. specimens were collected on an unidentified red gorgonian from a depth of $16 \mathrm{~m}$ (Fig. 6A). 


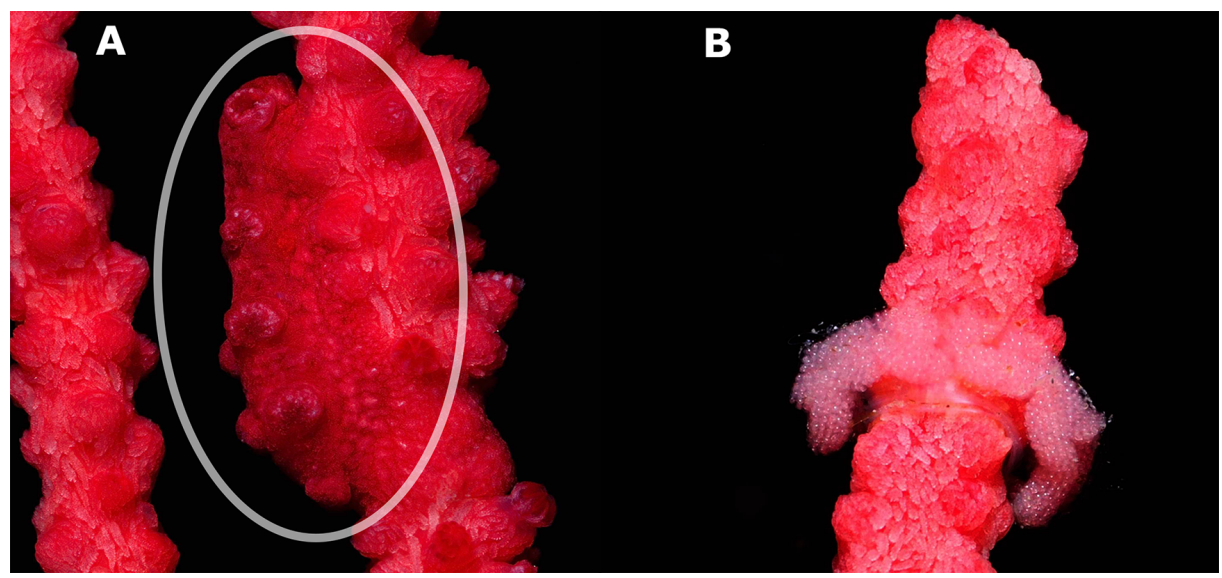

Figure 6. Marionia abrahamorum sp. nov., mature adult. (A) Specimen (circled) on left side of branch of unidentified gorgonian showing its cryptic coloration; (B) spawning mass.

Etymology.-This species is named Marionia abrahamorum in honor of Aketza Herrero's wife, Luz María Gonzalez Abraham, and his mother-in-law's family.

Geographical Distribution.-Marionia abrahamorum sp. nov. has only been reported from Príncipe Island.

\section{DiscusSION}

The small body size, alternating gill sizes, and simple velar papillae in the examined specimens are external morphological features that presumably characterize the genus Tritonia (Odhner 1963). However, hard stomach plates and a digestive gland divided into two lobes are features usually found in the genus Marionia (Odhner 1963, Marcus Ev. 1983). This confusion exemplifies the need to find better morphological characters as key features to distinguish the genera of Tritoniidae. To safely assign the new species to the genus Marionia, this description was based not only on internal morphological features, but also on results from molecular phylogenetic analyses. Table 4 compares morphological features among Atlantic species of Marionia.

When compared with M. cabindae, M. vanira, M. pusa, and M. ghanensis, the four Marionia species from the western coast of Africa, M. abrahamorum sp. nov. presents enough external and internal differences to be considered a different species. Among these species, $M$. abrahamorum sp. nov. has the fewest gills, fewer rows of denticles on the inner edge of the jaws, and the smallest radular formula (Table 4). Among the four species of Marionia known from the western African coast, color in life is only known for M. ghanensis, the only one described from a fresh specimen (Edmunds and Carmona 2017), and its purple color does not match the reddish color of $M$. abrahamorum sp. nov. Moreover, the notum of $M$. abrahamorum sp. nov. does not show any reticulation as described in $M$. vanira, nor the white rings found in $M$. ghanensis and M. pusa, being more similar to the "papillose notum" of M. cabindae. Although stomach plates were not noted in the latter species, these plates are easily distinguished in $M$. abrahamorum sp. nov. The lower numbers of veil appendages, gills, rows of denticles on the inner edge of the jaws, smaller radular formula, and 


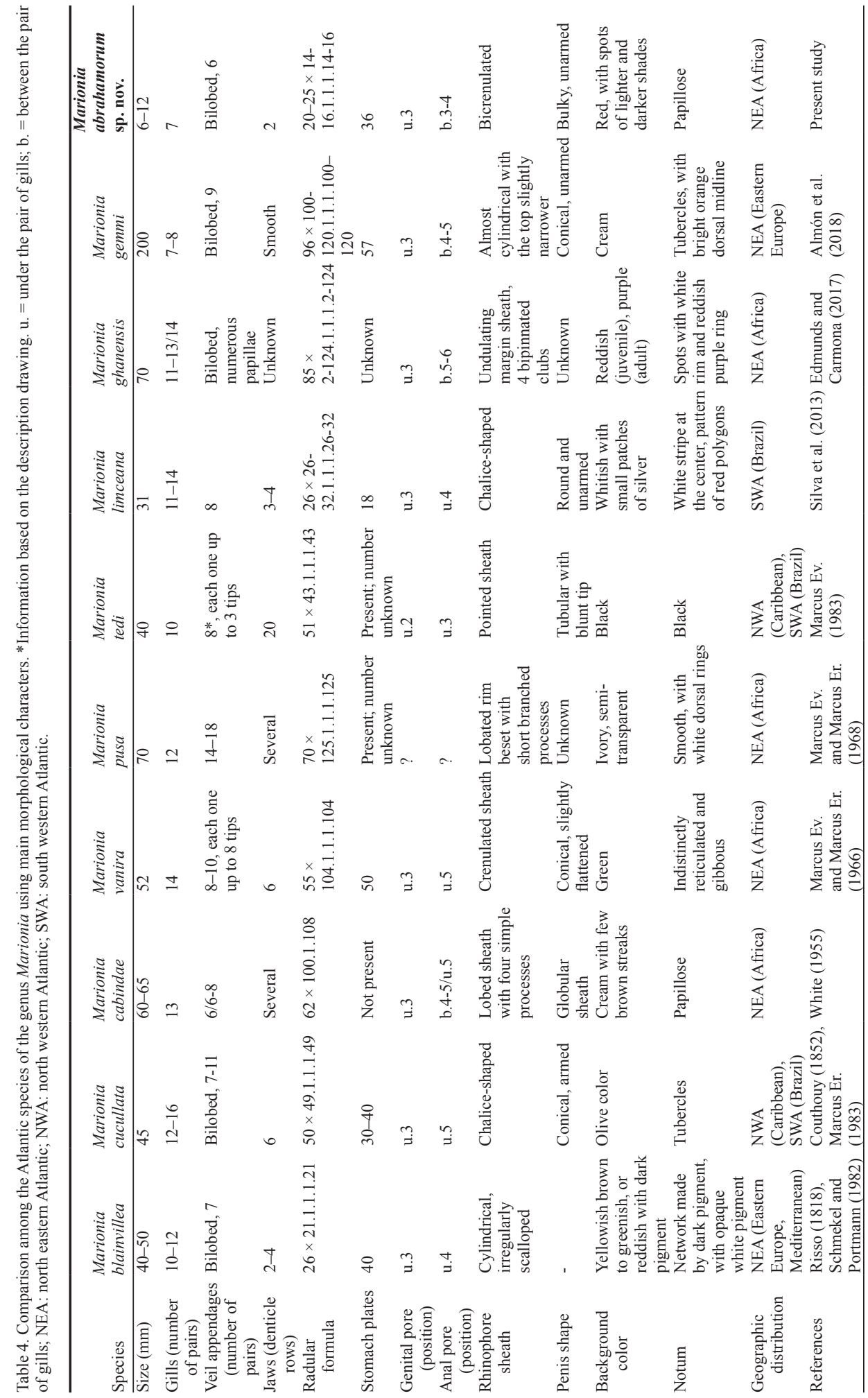


background color also allow us to differentiate $M$. abrahamorum sp. nov. from the remaining Marionia species found in the Atlantic Ocean: the western M. cucullata, M. tedi, and M. limceana, and the giant European M. gemmi (Table 4).

However, the Atlantic M. blainvillea and the Indo-Pacific Marionia bathycarolinensis V.G. Smith and Gosliner, 2005 share a similar background color with $M$. abrahamorum sp. nov; the former can display yellowish to green as its background color and M. bathycarolinensis was described as "brick red." However, these two species may be easily differentiated from our new species by the color patterns on their notum; $M$. blainvillea has a network of dark reddish pigment with opaque white spots (Table 4), while M. bathycarolinensis does not display any pattern at all, only "patches of greenish tinge" (Smith and Gosliner 2005). Additionally, $M$. bathycarolinensis is a giant compared to M. abrahamorum sp. nov., with the preserved holotype of $M$. bathycarolinensis described as measuring $155 \mathrm{~mm}$ in length, with 25 or more rows of denticles on the inner edge of the jaws, and a radular formula of $72 \times 142.1 .1 .142$ (Smith and Gosliner 2005), whereas the largest specimen of M. abrahamorum sp. nov. is $12 \mathrm{~mm}$ long and has 2 rows of denticles on the inner edge of the jaws, and a radula formula of $25 \times 10-16.1 .1 .1 .10-16$. Additionally, $M$. abrahamorum sp. nov., at up to $12 \mathrm{~mm}$ long, is also the smallest Atlantic Marionia species; the remaining species range from $31 \mathrm{~mm}$ (M. limceana) to $200 \mathrm{~mm}(M$. gemmi). As a side note, the bursa copulatrix in most Marionia species is generally equal to or larger than the rest of the reproductive mass but is smaller in $M$. abrahamorum sp. nov. The shape of the ampulla is also not typical for the genus, being spherical and small when compared to the large, long, bulky, convoluted, or folded ampullae of the other described Marionia (Marcus Ev. and Marcus Er. 1968, Marcus Ev. 1983, Smith and Gosliner 2005, 2007, Silva et al. 2013, Almón et al. 2018).

Our study did not recover Tritoniidae as monophyletic, in agreement with the conclusions of other recent studies (Pola and Gosliner 2010, Hulett et al. 2015, Mahguib and Valdés 2015). Although the species of Tritoniidae included in our analysis were clustered into seven different clades with poorly supported basal nodes, one of the clades was well supported and nested five undescribed species of Tritoniidae and all the Marionia species, including M. blainvillea, a result similar to recent studies including this genus (Almón et al. 2018, Valdés et al. 2018). Nevertheless, unravelling the phylogeny of the Tritoniidae is beyond the scope of our study, which aimed to show that M. abrahamorum sp. nov. is a valid species in the Marionia genus. Given that M. blainvillea is the type species of the genus, it is safe to assume that our species belong to the genus Marionia, since they cluster together, supporting the morphological data presented above. The BI and ML analyses, $p$-distance, and ABGD species delimitation analysis also strongly support the hypothesis that $M$. abrahamorum sp. nov. is a new and valid species.

\section{ACKNOWLEDGMENTS}

We thank the Regional Government of Príncipe Island and the entire team at the UNESCO Biosphere Reserve of Príncipe Island for their support and logistical assistance during Marine Expedition BIO-Príncipe 2016. We thank P Kohnert (Zoologische Staatssammlung München) for the assistance with the scanning electron nicroscope. We also thank C Farias from the Instituto Español de Oceanografía for the Marionia sp. 1 specimen (MB28-005057). FdVS has a PhD scholarship from the CNPq-Brazil (232557/2014-4). 


\section{Literature Cited}

Akaike H. 1974. A new look at the statistical model identification. IEEE Trans Automat Contr. 19(6):716-723. https://doi.org/10.1109/TAC.1974.1100705

Almón B, Pérez J, Caballer M. 2018. Expect the unexpected: a new large species of Marionia (Heterobranchia: Nudibranchia: Tritoniidae) from western Europe. Invertebr Syst. 32(4):892-908. https://doi.org/10.1071/IS17073

Altschul SF, Gish W, Miller W, Myers EW, Lipman DJ. 1990. Basic local alignment search tool. J Mol Biol. 215:403-410. https://doi.org/10.1016/S0022-2836(05)80360-2

Bertsch H. 2014. Biodiversity in La Reserva de la Biósfera Bahía de los Ángeles y Canales de Ballenas y Salsipuedes: naming of a new genus, range extensions and new records, and species list of Heterobranchia (Mollusca: Gastropoda), with comments on biodiversity conservation within marine reserves. Festivus. 46:158-175.

Bertsch H, Valdés A, Gosliner TM. 2009. A new species of tritoniid nudibranch, the first found feeding on a zoanthid anthozoan, with a preliminary phylogeny of the Tritoniidae. Proc Calif Acad Sci. 60:431-446.

Colgan DJ, McLauchlan A, Wilson GDF, Livingston SP, Edgecombe GD, Macaranas J, Cassis G, Gray MR. 1998. Histone H3 and U2 snRNA DNA sequences and arthropod molecular evolution. Aust J Zool. 46(5):419-437. https://doi.org/10.1071/zo98048

Couthouy JP. in Gould. 1852. Mollusca and shells. United States Exploring Expedition 12. Gould and Lincoln: Boston. 510.

Edmunds M, Carmona L. 2017. Heterobranchia Mollusca from Ghana: the traditionally called Dendronotacea and Arminacea. J Conchol. 42(5):339-356.

Folmer O, Black M, Hoeh W, Lutz R, Vrijenhoek R. 1994. DNA primers for amplification of mitochondrial cytochrome c oxidase subunit I from diverse metazoan invertebrates. Mol Mar Biol Biotechnol. 3:294-299.

Garcia FG, Bertsch H. 2009. Diversity and distribution of the Gastropoda Opisthobranchia from the Atlantic Ocean: a global biogeographic approach. Sci Mar. 73:153-160. https:// doi.org/10.3989/scimar.2009.73n1153

Goodheart JA. 2017. Insights into the systematics, phylogeny, and evolution of Cladobranchia (Gastropoda: Heterobranchia). Am Malacol Bull. 35(1):73-81. https://doi. org/10.4003/006.035.0111

Gosliner TM, Behrens DW, Valdés Á. 2008. Indo-Pacific nudibranchs and sea slugs: a guide to the world's most diverse fauna. Sea Challengers Natural History Books; California Academy of Sciences.

Hulett RE, Mahguib J, Gosliner TM, Valdés Á. 2015. Molecular evaluation of the phylogenetic position of the enigmatic species Trivettea papalotla (Bertsch)(Mollusca: Nudibranchia). Invertebr Syst. 29(3):215-222. https://doi.org/10.1071/IS15002

Jeffroy O, Brinkmann H, Delsuc F, Philippe H. 2006. Phylogenomics: the beginning of incongruence? Trends Genet. 22:225-231. https://doi.org/10.1016/j.tig.2006.02.003

Kearse M, Moir R, Wilson A, Stones-Havas S, Cheung M, Sturrock S, Buxton S, Cooper A, Markowitz S, Duran C, et al. 2012. Geneious Basic: an integrated and extendable desktop software platform for the organization and analysis of sequence data. Bioinformatics. 28(12):1647-1649. https://doi.org/10.1093/bioinformatics/bts199

Lanfear R, Frandsen BP, Wright AM, Senfeld T, Calcott B. 2016. PartitionFinder 2: new methods for selecting partitioned models of evolution for molecular and morphological phylogenetic analyses. Mol Biol Evol. 34:772-773. https://doi.org/10.1093/molbev/msw260

McDonald GR, Nybakken JW. 1999. A worldwide review of the food of nudibranch mollusks. II. The suborder Dendronotacea. Veliger. 42:62-66.

Mahguib J, Valdés Á. 2015. Molecular investigation of the phylogenetic position of the polar nudibranch Doridoxa (Mollusca, Gastropoda, Heterobranchia). Polar Biol. 38(9):13691377. https://doi.org/10.1007/s00300-015-1700-5 
Marcus Ev, Marcus Er. 1966. Opisthobranchs from tropical West Africa. In: Bayer FM, Voss GL, Robins R, editors. The R/V Pillsbury deep-sea biological expedition to the Gulf of Guinea, 1964-1965. Stud Trop Ocean. 4(1):152-208.

Marcus Ev, Marcus Er. 1968. Some opisthobranchs from the Ivory Coast. Bull IFAN Ser A. 30:1334-1342.

Marcus Ev. 1983. The western Atlantic Tritoniidae. Bol Zoo Univ São Paulo. 6:177-214.

MolluscaBase. 2018. Marionia Vayssière, 1877. Accessed May 2, 2018. World Register of Marine Species. Availablefrom:http://www.marinespecies.org/aphia.php? $\mathrm{p}=$ taxdetails\&id=138579

Odhner NH. 1963. On the taxonomy of the family Tritoniidae (Mollusca: Opisthobranchia). Veliger. 6:48-62.

Palumbi SR, Martin A, Romano S, McMillan WO, Stice L, Grabowski G. 1991. The simple fool's guide to PCR. Honolulu, Hawaii: University of Hawaii.

Pola M, Gosliner TM. 2010. The first molecular phylogeny of cladobranchian opisthobranchs (Mollusca, Gastropoda, Nudibranchia). Mol Phylogenet Evol. 56:931-941. https://doi. org/10.1016/j.ympev.2010.05.003

Puillandre N, Lambert A, Brouillet S, Achaz G. 2012. ABGD, automatic barcode gap discovery for primary species delimitation. Mol Ecol. 21:1864-1877. https://doi. org/10.1111/j.1365-294X.2011.05239.x

Rambaut A, Suchard MA, Xie D, Drummond AJ. 2014. Tracer v1.6. Available from: http://tree. bio.ed.ac.uk/software/tracer/

Risso A. 1818. Mémoire sur quelques Gastropodes nouveaux, Nudibranches et Tectibranches observés dans la mer de Nice. J Phys Chim Hist Nat Arts. 87:368-377.

Ronquist F, Huelsenbeck JP. 2003. MrBayes 3: Bayesian phylogenetic inference under mixed models. Bioinformatics. 19:1572-1574. https://doi.org/10.1093/bioinformatics/btg180

Schmekel L, Portmann A, Richter I, Bousani-Baur S. 1982. Opisthobranchia des Mittelmeeres. Springer Science \& Business Media.

Silva FDV, De Meirelles CAO, Matthews-Cascon H. 2013. A new species of Marionia (Opisthobranchia: Nudibranchia: Tritoniidae) from the tropical South Atlantic Ocean. J Mar Biol Assoc U K. 93(6):1617-1624. https://doi.org/10.1017/S0025315412001671

Smith VG, Gosliner TM. 2005. A new species of Marionia (Gastropoda: Nudibranchia) from the Caroline Islands. Proc Calif Acad Sci. 56(6):66-75.

Smith VG, Gosliner TM. 2007. Two new species of Marionia (Mollusca: Nudibranchia) from the Indo-Pacific Region. Veliger. 48:260-275.

Stamatakis A. 2006. RAxML-VI-HPC: maximum likelihood-based phylogenetic analyses with thousands of taxa and mixed models. Bioinformatics. 22:2688-2690. https://doi. org/10.1093/bioinformatics/btl446

Stöver BC, Müller KF. 2010. TreeGraph 2: combining and visualizing evidence from different phylogenetic analyses. BMC Bioinformatics. 11(1):7. https://doi.org/10.1186/1471-2105-11-7

Talavera G, Castresana J. 2007. Improvement of phylogenies after removing divergent and ambiguously aligned blocks from protein sequence alignments. Syst Biol. 56:564-577. https:// doi.org/10.1080/10635150701472164

Tamura K, Peterson D, Peterson N, Stecher G, Nei M, Kumar S. 2011. MEGA5: molecular evolutionary genetics analysis using maximum likelihood, evolutionary distance, and maximum parsimony methods. Mol Phyl Evol. 28:2731-2739. https://doi.org/10.1093/molbev/ msr121

Valdés Á, Lundsten L, Wilson NG. 2018. Five new deep-sea species of nudibranchs (Gastropoda: Heterobranchia: Cladobranchia) from the northeast Pacific. Zootaxa. 4526(4):401-433. https://doi.org/10.11646/zootaxa.4526.4.1

White K. 1955. Some opisthobranchs from West Africa. Bulletin of the Royal Belgian Institute of Natural Sciences - scientific results of the Belgian oceanographic expedition in African coastal waters of the South Atlantic (1948-1949). 3(4(4)):163-195. 
Xia X, Lemey P. 2009. Assessing substitution saturation with DAMBE. In: Lemey P, Salemi M. VanDamme AM, editors. The phylogenetic handbook: a practical approach to dna and protein phylogeny, 2nd ed. Cambridge UK: Cambridge University Press. p. 615-630.

Xia X, Xie Z. 2001. DAMBE: data analysis in molecular biology and evolution. J Hered. 92:371373. https://doi.org/10.1093/jhered/92.4.371

Xia X, Xie Z, Salemi M, Chen L, Wang Y. 2003. An index of substitution saturation and its application. Mol Phylogenet Evol. 26:1-7. https://doi.org/10.1016/S1055-7903(02)00326-3 